\title{
Occurrence of anti-Toxoplasma gondii and anti-Neospora caninum antibodies in pigs in the State of Pará, Brazil
}

\author{
Ocorrência de anticorpos contra Toxoplasma gondii e Neospora caninum em \\ suínos no estado do Pará, Brasil \\ Leonardo Machado Lopes; Antonio Humberto Hamad Minervino ${ }^{2 *}$ (D); Suellen da Gama Barbosa Monger; \\ Herbert Sousa Soares4; Juliana Machado Portela²; Juliana Isabel Giuli da Silva Ferreira5; \\ Solange Maria Gennari ${ }^{4,5}$; Washington Luiz Assunção Pereira ${ }^{6}$ \\ Museu Paraense Emílio Goeldi - MPEG, Belém, PA, Brasil \\ ${ }^{2}$ Laboratório de Sanidade Animal - LARSANA, Universidade Federal do Oeste do Pará - UFOPA, Santarém, PA, Brasil \\ ${ }^{3}$ Laboratório Patologia, Instituto Evandro Chagas - IEC, Belém, PA, Brasil \\ ${ }^{4}$ Programa de Pós-graduação em Saúde Única e Bem-Estar Animal, Universidade Santo Amaro - UNISA, São Paulo, SP, Brasil \\ ${ }^{5}$ Faculdade de Medicina Veterinária e Zootecnia - FMVZ, Universidade de São Paulo - USP, São Paulo, SP, Brasil \\ ${ }^{6}$ Programa de Pós-graduação em Saúde e Produção Animal na Amazônia, Universidade Federal Rural da Amazônia - UFRA, Belém, PA, \\ Brasil
}

How to cite: Lopes LM, Minervino AHH, Monger SGB, Soares HS, Portela JM, Ferreira, JIGS et al. Occurrence of anti-Toxoplasma gondii and anti-Neospora caninum antibodies in pigs in the State of Pará, Brazil. Braz J Vet Parasitol 2021; 30(1): e017520. https:// doi.org/10.1590/S1984-296120201085

\begin{abstract}
We investigated the occurrence of Toxoplasma gondii and Neospora caninum antibodies in pigs raised in the Northeast of Pará, Brazil. At Study I, convenience sampled 151 pigs at two slaughterhouses, with and without state inspection; and Study II, which assessed 159 pigs with probabilistic sampling from nine pig farms. Serological analysis was performed using indirect fluorescent antibody test for $T$. gondii and N. caninum with a cutoff of 64 and 50, respectively. Overall, $6.77 \%$ pigs were seropositive for T. gondii and 5.16\% for N. caninum. In Study I, pigs slaughtered with and without state inspection presented similar occurrence for both coccidia $(p>0.05)$. Study II found an association between $N$. caninum seropositivity and sludge discarded into the soil, feeding pigs with animal-based protein, subsistence system, and absence of nipple drinkers. No association was found for T. gondii. Pigs from Pará are a potential source of $T$. gondii infection to humans. To our best knowledge, this is the first study to report anti-N. caninum antibodies in the serum of pigs in Pará State, Brazilian Amazon.
\end{abstract}

Keywords: Swine, coccidian, Brazilian Amazon, Toxoplasma gondii, Nespora caninum.

\section{Resumo}

Foi investigada a ocorrência de anticorpos contra Toxoplasma gondii e Neospora caninum em suínos criados no nordeste do Pará, Brasil. No Estudo I, foram amostrados 151 porcos em dois matadouros, com e sem inspeção estadual. O Estudo Il avaliou 159 suínos com amostragem probabilística de nove granjas de suínos. Para sorologia, utilizou-se o teste de imunofluorescência indireta para T. gondii e N. caninum com ponto de corte de 1:64 e 1:50, respectivamente. No geral, $6,77 \%$ dos suínos foram soropositivos para T. gondii e $5,16 \%$ para N. caninum. No Estudo I, suínos abatidos em matadouros com e sem inspeção estadual apresentaram ocorrência semelhante para ambos os coccídios ( $p>0,05)$. Os animais amostrados de Belém, Benevides, Marituba, Bujaru, Castanhal e Igarapé-Miri foram positivos para T. gondii, enquanto os soropositivos para N. caninum foram encontrados em Belém, Bujaru, Castanhal e Santo Antônio do Tauá. O Estudo II encontrou associação entre soropositividade de N. caninum e esterco descartado no solo, alimentação dos suínos com proteína de origem animal, criação de subsistência e ausência de bebedores tipo "nipple". Não foi encontrada associação para T. gondii. A carne suína apresenta potencial risco de transmissão de T. gondii para os habitantes da região. De acordo com nosso conhecimento, este é o primeiro relato de anticorpos anti-N. caninum em suínos no estado do Pará, Amazônia brasileira.

Palavras-chave: Suínos, coccídios, Amazônia, Toxoplasma gondii, Nespora caninum. 


\section{Introduction}

Data from the latest agricultural census demonstrates the robustness of Brazilian pig farming, with the production of pig meat having almost doubled between 1996 and 2006, from 1.2 to 2.3 million tons. This improvement has been boosted by the increase in the exports that quadrupled in the same period, from $4.5 \%$ to $21.1 \%$ (IBGE, 2017). In contrast, in the northern region, pig farming did not show the same technological improvement and was characterized by subsistence production (self-consumption) or as a complementary source of income through regular or sporadic marketing in local consumer markets. In the State of Pará, the expansion of cattle farming has coincided with a sharp decline in the number of pig farms, which has practically not evolved over the years, being restricted to small properties (Silva et al., 2017).

Toxoplasma gondii is an intracellular protozoan that is distributed worldwide and is capable of infecting birds and mammals, including humans, with an estimated global seroprevalence of 19\% (95\% confidence interval [Cl]: 17-22\%) in pigs (Foroutan et al., 2019). In the Amazon region, serological studies have already demonstrated the prevalence of $T$. gondii in wild animals (Minervino et al., 2010; Soares et al., 2011; Vitaliano et al., 2015) including primates (Minervino et al., 2017), dogs (Valadas et al., 2010; Minervino et al., 2012), horses (Moreira et al., 2019) and pigs (Cavalcante et al., 2006; Freitas et al., 2009; Sousa et al., 2014). To our best knowledge, there is only one report on the occurrence of $T$. gondii antibodies in pigs in Pará State, which was limited to the municipality of Belém (Freitas et al., 2009), and reported that 50\% (55/110) of the tested animals were seropositive.

In pigs, the main form of $T$. gondii infection is horizontal transmission; however, transplacental transmission is responsible for clinical manifestations of fetal death and mummification, preterm births, and varied symptoms (Dubey, 2009).

Neospora caninum is an intracellular protozoan that causes multisystem infection, and has domestic and wild canids (dingo, coyote, and gray wolf) as definitive hosts, and several warm-blooded animals as intermediate hosts (Donahoe et al., 2015; Cerqueira-Cézar et al., 2017). Studies in the State of Pará found N. caninum antibodies in cattle (Minervino et al., 2008; Chiebao et al., 2015) and dogs (Paz et al., 2019) however, there are no reports on the occurrence of $N$. caninum in pigs in this region.

Considering the lack of studies regarding the occurrence of $T$. gondii in the region and that infection by this parasite in pigs continues to be of public health concern (Dubey et al., 2020), and due pigs being a possible source of infection to $N$. caninum definitive hosts, this study aimed to determine the presence of antibodies and the associated risk factors against both parasites in pigs reared in the State of Pará, Brazil.

\section{Material and Methods}

This study was approved by the Animal Ethics Commission of the Federal Rural University of Pará (protocol 038/2013, and process 23084.010923/2013-15).

\section{Study area}

The study was conducted in the Northeast of Pará state, Northern Brazil, located in the Amazon Biome (Figure 1). The climate of the region is characterized by an annual mean temperature of $25.9{ }^{\circ} \mathrm{C}$ and an annual mean rainfall of 2,150 mm, with a strong concentration from January to June, and more rarely, from July to December (Martorano et al., 2017).

Two different serological studies were conducted during the study period: Study I was performed as initial screening for the occurrence of T. gondii and N. caninum in the region, and Study II was a cross-sectional epidemiological survey.

Study I sampled a total of 151 pigs by convenience sampling method at two slaughterhouses - one with State Inspection Service $(S I S)(n=96)$ and the other without SIS $(n=55)$. At the initial screening, all animals were adults. The only information available was the origin of the pigs. Animals from three distinct regions of Pará State, Northeast, Marajó, and Belém Metropolitan area, were included in this study. Pigs where from the following cities Bujaru, Castanhal, Belém, Marituba and from the Marajó island. (unknown city).

Study II was a prospective cross-sectional epidemiological survey of pig farms from the Northeast and Belém metropolitan areas of Pará State. The number of animals to be sampled was calculated using the Epi Info ${ }^{\mathrm{TM}}$ software 
LEGEND

$\odot$ State Capital

- City

Waters

Municipalities included in the study

Municipality boundaries

Northeast of Pará
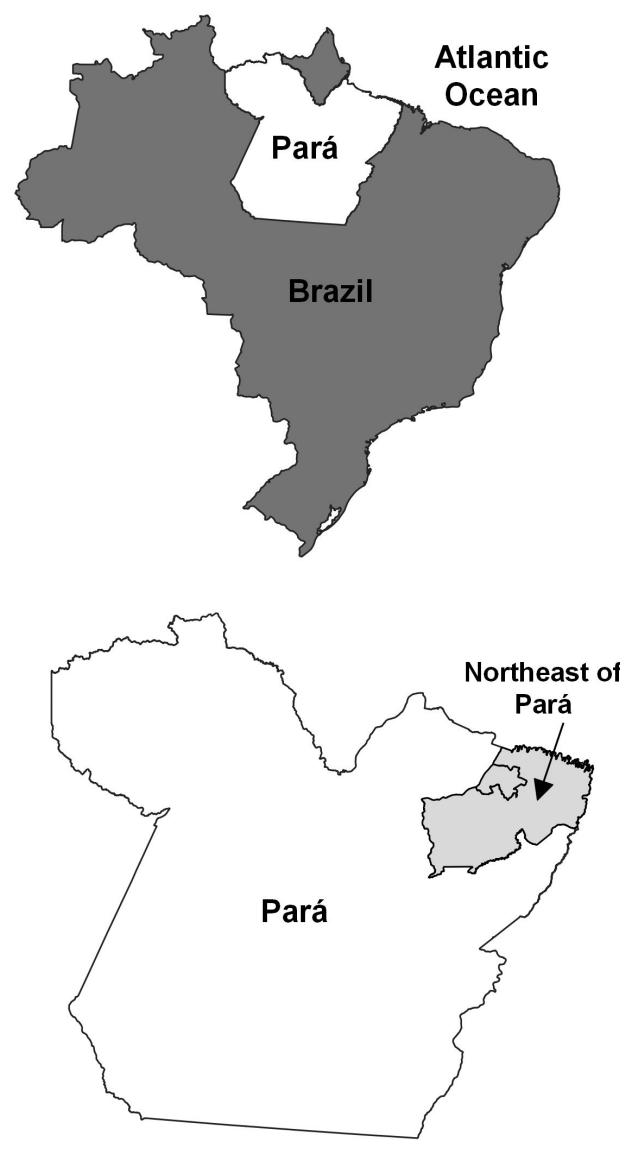
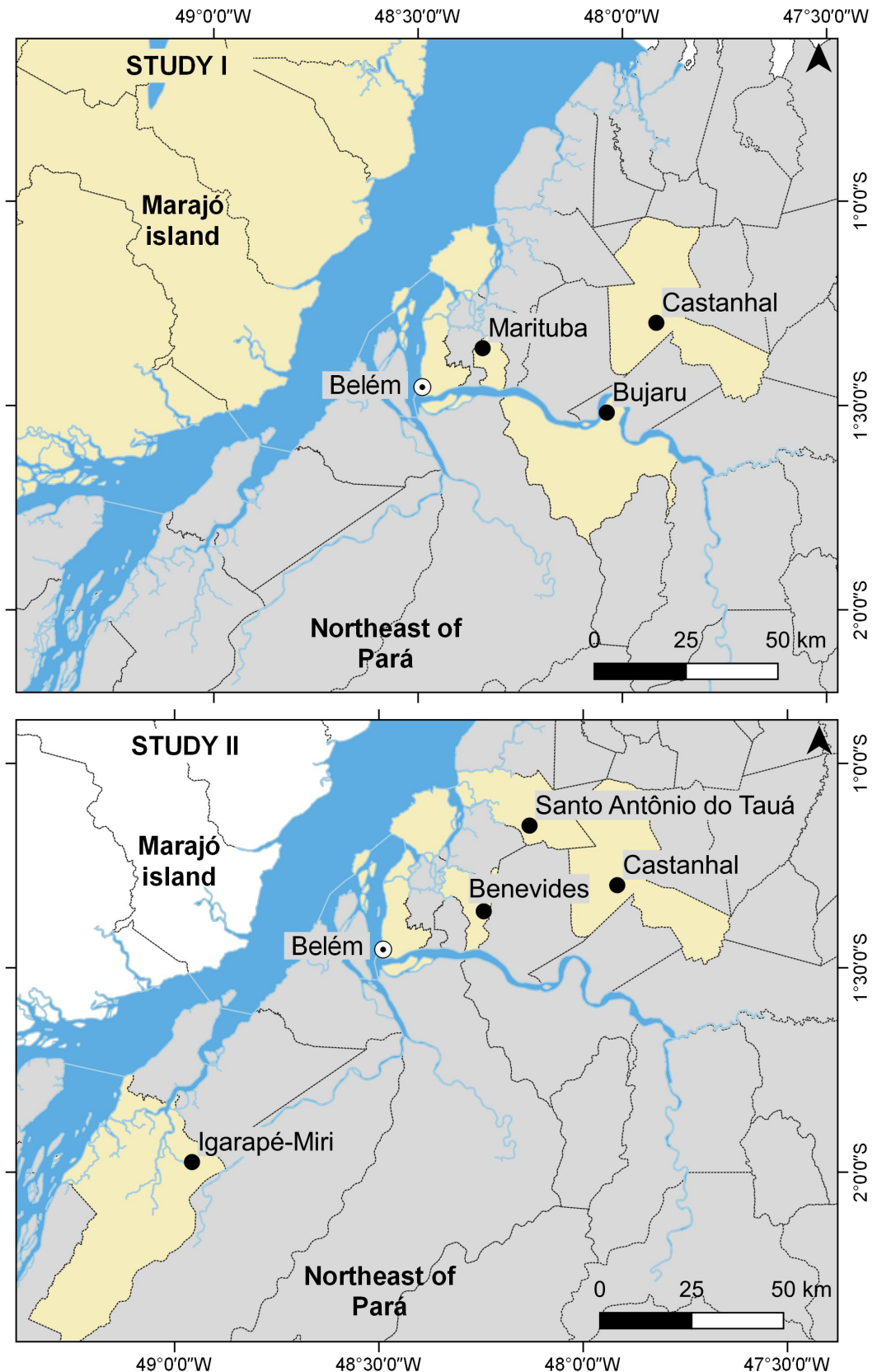

Figure 1. Study site with the municipalities included in Study I and Study II. In the study I samples were from Marajó island but the specific municipality could not be confirmed.

(U.S. Centers for Disease Control and Prevention, Atlanta, USA) with the following parameters: herd population $(41,443,594$ pigs); expected prevalence of 9.3 (based on the $T$. gondii results of Study l, which presented the highest occurrence), expected error of 5\%, and confidence interval of 97\%, which indicated the requirement for 129 samples. Thus, blood samples from 159 pigs were collected from nine pig farms. A epidemiological questionnaire was applied to the individuals responsible for the farms, which had questions regarding facilities, type of management, production characteristics, hygiene-sanitary features, and the presence/absence of cats and dogs. The age of the pigs varied from one to seven months. Pigs were sampled in the following cities: Castanhal, Igarapé-miri, Santo Antônio do Tauá, Belém and Benevides.

For Study I, blood samples were obtained during the slaughter of the pigs. Samples for Study II were drawn by cephalic puncture of the pigs in the farms. The samples were kept at room temperature until clotting and then transported to the laboratory in an ice cooler. The serum was collected, centrifuged, and stored at $-20^{\circ} \mathrm{C}$ until analysis. 


\section{Serological analysis}

The presence of antibodies to $T$. gondii and $N$. caninum was determined by an indirect fluorescent antibody test (IFAT). The test antigens were derived from whole tachyzoites of the RH strain of $T$. gondii, maintained in Swiss albino mice, and from whole tachyzoites of the NC-1 strain of N. caninum, maintained in an M-617 monocyte culture (André et al., 2010).

The IFAT was performed according to previously described protocols using a 1:64 cutoff for $T$. gondii (Vidotto et al., 1990) and 1:50 cutoff for $N$. caninum (Azevedo et al., 2010). Positive and negative controls were added to each slide. Positive sera were subsequently diluted two-fold serially and the sample titer was the highest dilution which provided a positive result.

\section{Statistical analysis}

The frequency of positive results for each parasite was analyzed separately for Study I and Study II. Study I evaluated the association of seropositive animals with the municipality of origin and the presence or absence of SIS in the abattoir using the $\chi^{2}$ test or the Fisher exact test.

For Study II, the associations between the possible epidemiological risk factor variables and the prevalence of T. gondii and N. caninum antibodies were estimated using the $\chi^{2}$ test by the Mantel-Haenszel method, considering the serological status (positive or negative) of the animals as a dependent variable for each parasite studied. The odds ratios and respective $95 \%$ Cls were also calculated. The SAS statistical program was used, with at least 5\% $(p<0.05)$ significance level.

\section{Results}

The total number of pigs sampled in Studies I and II was 310, which presented an occurrence of 11.3\% (35/310) and 5.2\% (16/310) for T. gondii and N. caninum, respectively. The occurrence of antibodies to T. gondii and N. caninum in pigs from Studies I and II are presented in Table 1. Animals sampled from Belém, Benevides, Marituba, Bujaru, Castanhal, and Igarapé-Miri were positive for T. gondii, whereas those seropositive for $N$. caninum were found in Belém, Bujaru, Castanhal, and Santo Antônio do Tauá.

Table 1. Frequency of antibodies to T. gondii and N. caninum in the sera of pigs from slaughterhouses (Study I) or free reared (Study II) in the State of Pará.

\begin{tabular}{cccccc}
\hline \multirow{2}{*}{ Study } & \multicolumn{2}{c}{ Toxoplasma gondii } & & \multicolumn{2}{c}{ Neospora caninum } \\
\cline { 2 - 3 } \cline { 5 - 6 } & Positive/tested & $\%$ & & Positive/tested & 4.6 \\
\hline II & $14 / 151$ & 9.3 & $7 / 151$ & 5.7 \\
Overall & $21 / 159$ & 13.2 & $9 / 159$ & 5.2 \\
\hline
\end{tabular}

No association was observed between the frequency of pigs positive for T. gondii and N. caninum and abattoirs with and without SIS (p>0.05). Six of $96(6.25 \%)$ and 8 of 55 (14.54\%) pigs were seropositive for T. gondii in slaughterhouses with and without SIS, and 3 of 96 (3.13\%) and 4 of 55 (7.27\%) pigs were seropositive for N. caninum in the slaughterhouses with and without SIS, respectively.

The number of pigs positive for T. gondii and $N$. caninum, stratified by age groups, in Study II are presented in Tables 2 and 3, respectively. Antibodies against $N$. caninum were observed in piglets aged less than 1, 3, 4, and 6 months of age. No statistical difference was observed in pigs for both $T$. gondii and $N$. caninum when stratified by their age group ( $p>0.05)$.

In Study II, the associations between the presence of $T$. gondii and $N$. caninum and the following variables in seropositive animals were analyzed: presence of cats, presence of dogs, sludge discarded into the soil, feeding pigs with animal-origin protein, subsistence system or intensive confinement system, type of drinker, and breeding together with ruminant or poultry. There was no association between seropositivity to $T$. gondii and the variables evaluated. The presence of antibodies to $N$. caninum was associated with the following variables: sludge discarded into the soil, feeding pigs with animal-origin protein, and absence of suction (nipple) drinkers (Table 4). 
Table 2. Study II: Frequency of $T$. gondii seropositive pigs stratified by antibody titers and age groups.

\begin{tabular}{|c|c|c|c|c|c|c|c|}
\hline \multirow{2}{*}{$\begin{array}{c}\text { Age } \\
\text { (months) }\end{array}$} & \multirow{2}{*}{$\mathbf{N}$} & \multirow{2}{*}{$\mathbf{P}$} & \multirow{2}{*}{$\%$} & \multicolumn{4}{|c|}{ Titer } \\
\hline & & & & 64 & 256 & 512 & 2048 \\
\hline$<1^{*}$ & 18 & 4 & 22.2 & 0 & 1 & 3 & 0 \\
\hline 1 & 31 & 0 & 0 & 0 & 0 & 0 & 0 \\
\hline 2 & 43 & 0 & 0 & 0 & 0 & 0 & 0 \\
\hline 3 & 24 & 0 & 0 & 0 & 0 & 0 & 0 \\
\hline 4 & 19 & 0 & 0 & 0 & 0 & 0 & 0 \\
\hline 5 & 15 & 2 & 13.1 & 0 & 0 & 1 & 1 \\
\hline 6 & 9 & 1 & 11.1 & 1 & 0 & 0 & 0 \\
\hline Total & 159 & 7 & 46.4 & 1 & 1 & 4 & 1 \\
\hline
\end{tabular}

$\mathrm{N}$, number of pigs; $\mathrm{P}$, number of positive pigs; \%, percentage of positive pigs; *seropositivity in piglets less than 1 month is probably due to colostrum antibodies.

Table 3. Study II: Frequency of seropositive pigs to N. caninum by age and antibody titers.

\begin{tabular}{|c|c|c|c|c|c|c|c|}
\hline \multirow{2}{*}{ Age (months) } & \multirow{2}{*}{$\mathbf{N}$} & \multirow{2}{*}{$\mathbf{P}$} & \multirow{2}{*}{$\%$} & \multicolumn{4}{|c|}{ Titer } \\
\hline & & & & 50 & 100 & 200 & 400 \\
\hline$<1^{*}$ & 18 & 2 & 11.1 & 1 & 1 & 0 & 0 \\
\hline 1 & 31 & 0 & 0 & 0 & 0 & 0 & 0 \\
\hline 2 & 43 & 0 & 0 & 0 & 0 & 0 & 0 \\
\hline 3 & 24 & 3 & 12.5 & 1 & 0 & 1 & 1 \\
\hline 4 & 19 & 2 & 10.5 & 0 & 1 & 0 & 1 \\
\hline 5 & 15 & 0 & 0 & 0 & 0 & 0 & 0 \\
\hline 6 & 9 & 2 & 22.2 & 2 & 0 & 0 & 0 \\
\hline Total & 159 & 09 & 56.3 & 4 & 2 & 1 & 2 \\
\hline
\end{tabular}

$\mathrm{N}$, number of pigs; $\mathrm{P}$, number of positive pigs; \%, percentage of positive pigs; *seropositivity in piglets less than 1 month is probably due to colostrum antibodies.

Table 4. Study II: Analysis of risk factors for infection by N. caninum in pigs reared in the Belém Metropolitan and Northeast regions of Pará State, Brazil

\begin{tabular}{ccccc}
\hline Variables & \multicolumn{3}{c}{ N. caninum } \\
\cline { 2 - 5 } Swage release in the area & \multicolumn{1}{c}{ P-value } & OR & 95\% Cl \\
\hline Feed animal with meat residues from slaughterhouses & 6.451 & 0.0111 & 7.913 & $1.246-24.069$ \\
Subsistence system & 11.195 & 0.0008 & 10.469 & $2.547-43.02$ \\
Nipple drinkers & 11.195 & 0.0008 & 0.095 & $0.023-0.392$ \\
\hline
\end{tabular}

OR, odds ratio; $\mathrm{Cl}$, confidence interval.

\section{Discussion}

T. gondii occurrence (6.77\%) in pigs from Pará was higher than that found in growing-finishing pigs in Paraná: 2.60\% (Carletti et al., 2005), and in pigs slaughtered in São Paulo and Minas Gerais: 0\% (Pezerico et al., 2007); in the later study, the absent of positive animals was probably due improvements in hygienic and sanitary management adopted in large-scale pig farming. It is noteworthy that infection with $T$. gondii is widespread in our study area, which was verified in 6 of the 7 municipalities investigated $(85.71 \%)$. 
In contrast, the frequency of infection was lower than that observed in slaughter pigs in the state of Paraíba, with occurrence of 36.2\% (Azevedo et al., 2010) and 19.5\% (Feitosa et al., 2014). Although infection rates may vary in finishing and slaughter pigs, in the breeding stock, the infection is generally high, as was verified in Alagoas (26.9\%) (Valença et al., 2011) and Paraná (35\%) (Tsutsui et al., 2003), probably due to the longer time of exposure to the agent (Carletti et al., 2005).

In the present study, $22.2 \%$ of the piglets ( $<1$ month of age) had antibodies to T. gondii, and positive animals were found at 5 months of age. Pigs with 2,3, and 4 months of age were all seronegative, reinforcing the presence of colostral antibodies in the first month of age. This was also observed in Spain (García-Bocanegra et al., 2010), where a higher seroprevalence was found in pigs from 1-3 weeks of age born to positive mothers. In piglets born from sows with low antibody titers, the persistence of colostral antibodies is short, ending as soon as weaning occurs (Solaymani-Mohammadi \& Petri, 2006).

T. gondii-positive pigs were found at 5 and 6 months of age, indicating a possible horizontal infection from that age. The rate of infection is influenced by the length of stay on the property, with the prevalence of $T$. gondii antibodies higher in boars and sows due more time for horizontal transmission to occur (Vidotto et al., 1990; Dubey, 2016).

Limited reports deal with $N$. caninum in pigs, and this is the first study from Para State and one of the few worldwide that evaluated risk factors for parasite prevalence. Since $N$. caninum infection is restricted to animals, its presence in pig farms does not pose a human health concern, and the pigs are restricted to being a possible source of infection for the parasite definite host (Cerqueira-Cézar et al., 2017). This may explain the lack of more surveys of $N$. caninum in pigs worldwide, especially in Brazil.

Among pigs, little is known about $N$. caninum infection and reproductive problems. Jensen et al. (1998) experimentally infected pregnant pigs with $N$. caninum and observed disease caused by the parasite in the sows and also transplacental infection. However, Helmick et al. (2002) analyzed serum samples from 454 breeding sows with a history of abortion and infertility, all of which were negative.

The frequency of infection by N. caninum in both Study I (4.6\%) and Study II (5.7\%) was higher than that found in a confinement system in Paraíba state (3.2\%) (Azevedo et al., 2010). However, they were lower than those recorded in the Bahia state $(7.5 \%)$, Brazil (Almeida, 2004) and in wild pigs from Mato Grosso do Sul State (10.8\%) (Soares et al., 2016), respectively, in the northeastern and central areas of Brazil. It is noteworthy that our survey involved animals of all ages, including newborn piglets less than 1 month of age. The positive results obtained from these animals were most likely due to colostrum consumption, resulting from immune system defense against an early life infection. Serological surveys in Brazil did not include newborn animals; hence, our results are difficult to compare.

Several risk factors were found to be associated with the presence of $N$. caninum antibodies, with a higher odds ratio to sewage disposal in the area, feeding the animals with slaughterhouse residues and subsistence system. Pigs reared in the subsistence system (with a familiarly workforce) were 10.5 times more likely to be $N$. caninum seropositive (95\% Cl: 2.5-43.0), whereas pigs with feed that included animal-origin protein, such as blood meal, were 7.9 more likely to be positive for $N$. caninum ( $95 \% \mathrm{Cl}$ : 1.6-39.6). This may be related to the poor sanitary conditions associated with subsistence farms, with intensive systems having greater hygiene control. Feeding pigs with animal protein was associated with $N$. caninum antibodies, which is explained by the possible presence of parasite oocysts in the animal meat, which, depending on the processing, can act as a source of infection to pigs through horizontal transmission (Dubey et al., 2017).

A positive association of antibodies to $\mathrm{N}$. caninum in farms that discard their sludge in the soil is another factor that can be associated with poor farm hygiene present mostly in subsistence farms. The absence of nipple drinkers was associated with pig infection and can be explained by the increase in water source contamination in other types of drinkers.

To the best of our knowledge, this is the first study to determine the occurrence of $N$. caninum in piglets of different ages. The occurrence of seropositive animals with less than 1 month of age was $11.11 \%$, with titers of 50 and 100, probably indicating colostral antibodies. Among weaned animals, seropositivity to $N$. caninum was only observed from 3 to 4 months of age, in which the titers varied between 50 and 400, remaining low (50) in the following months. This pattern is similar to that of T. gondii infection described by García-Bocanegra et al. (2010), in which seropositive piglets from the maternity showed a decrease in antibody titers after weaning, only developing seroconversion when entering the termination phase, where contact with contaminated food and water is greater. 
Animals slaughtered from abattoir with and without state inspection did not present different seroprevalence for both $T$. gondii and $N$. caninum. Slaughterhouse without inspection may receive animals from dubious origin which could had higher prevalence of diseases due to poor hygiene conditions, which was not observed in the present study. Such data is difficult to compare since most of the studies deal only with pigs from abattoir with inspection (Carletti et al., 2005; Feitosa et al., 2014), although in Pará state previous report show 50\% prevalence from animals slaughtered without inspection (Freitas et al., 2009).

T. gondii and $N$. caninum infection were associated with the presence of its respective definitive host in the farms (Dubey, 2009; Gui et al., 2020). We fail to detect any association with the presence of dogs and cats with the occurrence of antibodies to T. gondii and N. caninum in pigs from Northeast Pará. This may be related with the limited sample size or due to the access to the farm site by surrounding cats and dogs without the knowledge of the farmer, however this lack of association was also found in backyards pigs from Mato Grosso state, Brazil (Minetto et al., 2019).

In conclusion, reagent pigs to antibodies against T. gondii and N. caninum were found the State of Pará, Brazilian Amazon. No associations with the investigated risk factors was found for the prevalence of $T$. gondii antibodies in pigs. However, for N. caninum, subsistence farms, sludge discharge in the soil, absence of nipple drinkers, and feeding pigs with animal-origin protein were associated with a higher occurrence of seropositive pigs. Our analysis with piglets showed that newborn animals can acquire antibodies, probably due to colostral ingestion of the pathogen, and that seroconversion started at 5 months of age for $T$. gondii and at 4 months of age for $N$. caninum.

\section{Acknowledgements}

AHHM and SMG are grateful to CNPq for their research productivity fellowship.

\section{References}

Almeida M. Epidemiologia de Neospora caninum. Rev Bras Parasitol Vet 2004; 13(Supl. 1): 1.

André MR, Adania CH, Teixeira RHF, Silva KF, Jusi MMG, Machado STZ, et al. Antibodies to Toxoplasma gondii and Neospora caninum in Captive Neotropical and Exotic Wild Canids and Felids. J Parasito/ 2010; 96(5): 1007-1009. http://dx.doi.org/10.1645/ GE-2502.1. PMid:20950109.

Azevedo SS, Pena HF, Alves CJ, Guimarães AA Fo, Oliveira RM, Maksimov P, et al. Prevalence of anti-Toxoplasma gondii and anti-Neospora caninum antibodies in swine from Northeastern Brazil. Rev Bras Parasitol Vet 2010; 19(2): 80-84. http://dx.doi. org/10.1590/S1984-29612010000200002. PMid:20624342.

Carletti RT, Freire RL, Shimada MT, Ruffolo BB, Begale LP, Lopes FMR, et al. Prevalência da infecção por Toxoplasma gondii em suínos abatidos no Estado do Paraná, Brasil. Semina: Ciênc Agrár 2005; 26(4): 563. http://dx.doi.org/10.5433/1679-0359.2005v26n4p563.

Cavalcante GT, Aguiar DM, Chiebao D, Dubey JP, Ruiz VLA, Dias RA, et al. Seroprevalence of Toxoplasma gondii Antibodies in Cats and Pigs From Rural Western Amazon, Brazil.J Parasito/ 2006; 92(4): 863-864. http://dx.doi.org/10.1645/GE-830R.1. PMid:16995406.

Cerqueira-Cézar CK, Calero-Bernal R, Dubey JP, Gennari SM. All about neosporosis in Brazil. Rev Bras Parasitol Vet 2017; 26(3): 253-279. http://dx.doi.org/10.1590/s1984-29612017045. PMid:28876360.

Chiebao DP, Valadas SYOB, Minervino AHH, Castro V, Romaldini AHCN, Calhau AS, et al. Variables Associated with Infections of Cattle by Brucella abortus, Leptospira spp. and Neospora spp. in Amazon Region in Brazil. Transbound Emerg Dis 2015; 62(5): e30-e36. http://dx.doi.org/10.1111/tbed.12201. PMid:26302373.

Donahoe SL, Lindsay SA, Krockenberger M, Phalen D, Šlapeta J. A review of neosporosis and pathologic findings of Neospora caninum infection in wildlife. Int J Parasitol Parasites Wildl 2015; 4(2): 216-238. http://dx.doi.org/10.1016/j.ijppaw.2015.04.002. PMid:25973393.

Dubey JP, Cerqueira-Cézar CK, Murata FHA, Kwok OCH, Hill D, Yang YR, et al. All about Toxoplasma gondii infections in pigs: the past decade. Vet Parasito/ 2020; 288: 109185. http://dx.doi.org/10.1016/j.vetpar.2020.109185. PMid:33271424.

Dubey JP, Hemphill A, Calero-Bernal R, Schares G. Neosporosis in animals. Boca Raton: CRC Press; 2017. http://dx.doi. org/10.1201/9781315152561.

Dubey JP. Toxoplasmosis in pigs: the last 20 years. Vet Parasitol 2009; 164(2-4): 89-103. http://dx.doi.org/10.1016/j. vetpar.2009.05.018. PMid:19559531.

Dubey JP. Toxoplasmosis of animals and humans. 2nd ed. Boca Raton, Florida, USA: CRC Press; 2016. http://dx.doi. org/10.1201/9781420092370. 
Feitosa TF, Vilela VL, de Melo LR, de Almeida JL No, Souto DV, de Morais DF, et al. Toxoplasma gondii and Neospora caninum in slaughtered pigs from Northeast, Brazil. Vet Parasitol 2014; 202(3-4): 305-309. http://dx.doi.org/10.1016/j.vetpar.2014.03.015. PMid:24703253.

Foroutan M, Fakhri Y, Riahi SM, Ebrahimpour S, Namroodi S, Taghipour A, et al. The global seroprevalence of Toxoplasma gondii in pigs: A systematic review and meta-analysis. Vet Parasitol 2019; 269: 42-52. http://dx.doi.org/10.1016/j.vetpar.2019.04.012. PMid:31079827.

Freitas JA, Oliveira JP, Ramos OS, Ishizuka MM. Frequência de anticorpos anti-Toxoplasma gondii em suínos abatidos sem inspeção em Belém. Arq Bras Med Vet Zootec 2009; 61(5): 1230-1232. http://dx.doi.org/10.1590/S0102-09352009000500030.

García-Bocanegra I, Simon-Grifé M, DubeyJP, Casal J, Martín GE, Cabezón O, et al. Seroprevalence and risk factors associated with Toxoplasma gondii in domestic pigs from Spain. Parasitol Int 2010; 59(3): 421-426. http://dx.doi.org/10.1016/j.parint.2010.06.001. PMid:20601110.

Gui BZ, Lv QY, Ge M, Li RC, Zhu XQ, Liu GH. First report of Neospora caninum infection in pigs in China. Transbound Emerg Dis 2020; 67(1): 29-32. http://dx.doi.org/10.1111/tbed.13358. PMid:31538409.

Helmick B, Otter A, McGarry J, Buxton D. Serological investigation of aborted sheep and pigs for infection by Neospora caninum. Res Vet Sci 2002; 73(2): 187-189. http://dx.doi.org/10.1016/S0034-5288(02)00093-0. PMid:12204640.

Instituto Brasileiro de Geografia e Estatística - IBGE. Produção da Pecuária Municipal [online]. 2017 [cited 2020 Aug 1]. Available from: https://www.ibge.gov.br/estatisticas/economicas/agricultura-e-pecuaria/9107-producao-da-pecuaria-municipal. html?edicao=22651\&t=resultados

Jensen L, Jensen TK, Lind P, Henriksen SA, Uggla A, Bille-Hansen V. Experimental porcine neosporosis. APMIS 1998; 106(4): 475482. http://dx.doi.org/10.1111/j.1699-0463.1998.tb01374.x. PMid:9637270.

Martorano LG, Vitorino MI, Silva BPPC, Moraes JRSC, Lisboa LS, Sotta ED, et al. Climate conditions in the eastern amazon: rainfall variability in Belem and indicative of soil water deficit. Afr J Agric Res 2017; 12(21): 1801-1810. http://dx.doi.org/10.5897/ AJAR2016.11801.

Minervino AH, Soares HS, Barrêto-Júnior RA, Neves KA, Pena HF, Ortolani EL, et al. Seroprevalence of Toxoplasma gondii antibodies in captive wild mammals and birds in Brazil. J Zoo Wildl Med 2010; 41(3): 572-574. http://dx.doi.org/10.1638/20100046.1. PMid:20945665.

Minervino AHH, Cassinelli ABM, De Lima JTR, Soares HS, Malheiros AF, Marcili A, et al. Prevalence of anti- Neospora caninum and anti- Toxoplasma gondii antibodies in dogs from two different indigenous communities in the Brazilian Amazon Region.J Parasitol 2012; 98(6): 1276-1278. http://dx.doi.org/10.1645/GE-3151.1. PMid:22551468.

Minervino AHH, Cassinelli ABM, De Souza AJS, Alves MM, Soares MCP, Ferreira DAC, et al. Detection of Toxoplasma gondii antibodies in captive non-human primates in the Amazon region, Brazil. J Med Primatol 2017; 46(6): 343-346. http://dx.doi.org/10.1111/ jmp.12314. PMid:28972656.

Minervino AHH, Ragozo AMA, Monteiro RM, Ortolani EL, Gennari SM. Prevalence of Neospora caninum antibodies in cattle from Santarém, Pará, Brazil. Res Vet Sci 2008; 84(2): 254-256. http://dx.doi.org/10.1016/j.rvsc.2007.05.003. PMid:17619028.

Minetto MK, Witter R, Oliveira ACS, Minetto JA, Barros ML, Aguiar DM, et al. Antibodies anti-Toxoplasma gondii and anti-Neospora caninum in backyard pigs from the state of Mato Grosso, Brazil. Rev Bras Parasitol Vet 2019; 28(3): 403-409. http://dx.doi. org/10.1590/s1984-29612019050. PMid:31390435.

Moreira TR, Sarturi C, Stelmachtchuk FN, Andersson E, Norlander E, De Oliveira FLC, et al. Prevalence of antibodies against Toxoplasma gondii and Neospora spp. in equids of Western Pará Brazil. Acta Trop 2019; 189: 39-45. http://dx.doi.org/10.1016/j. actatropica.2018.09.023. PMid:30267659.

Paz GS, Colhado BS, Anton MM, Rocha KS, Silva DB, Moraes CCG, et al. Infecção por Toxoplasma gondii, Neospora caninum, Leishmania major e Trypanosoma cruzi em cães do estado do Pará. Cienc Anim Bras 2019; 20: e33566. http://dx.doi.org/10.1590/1809$6891 v 20$ e-33566.

Pezerico GB, Pezerico SB, Silva RC, Hoffmann JL, Camargo LB, Langoni H. Ocorrência de anticorpos anti-Toxoplasma gondii e anti-Leptospira spp. em suínos abatidos em três abatedouros dos estados de Minas Gerais e São Paulo. Arq Inst Biol (Sao Paulo) 2007; 74(3): 267-270.

Silva ICM, Bremm B, Teixeira JL, Costa NS, Barcellos JOJ, Braccini J, et al. Spatialization of Brazilian pig production: relationship between productive, physical, environmental, and socio-economic variables. Trop Anim Health Prod 2017; 49(5): 951-958. http:// dx.doi.org/10.1007/s11250-017-1281-0. PMid:28365820.

Soares HS, Minervino AHH, Barrêto-Júnior RA, Neves KAL, Oliveira MF, Santos JR, et al. Occurrence of Toxoplasma gondii Antibodies in Dasyprocta aguti from Brazil: Comparison of Diagnostic Techniques. J Zoo Wildl Med 2011; 42(4): 763-765. http://dx.doi. org/10.1638/2011-0136.1. PMid:22204080. 
Soares HS, Ramos VN, Osava CF, Oliveira S, Szabó MPJ, Piovezan U, et al. OOccurrence of antibodies against Neospora caninum in wild pigs (Sus scrofa) in the Pantanal, Mato Grosso do Sul, Brazil. Braz J Vet Res Anim Sci 2016; 53(1): 112-116. http://dx.doi. org/10.11606/issn.1678-4456.v53i1p112-116.

Solaymani-Mohammadi S, Petri WA Jr. Zoonotic implications of the swine-transmitted protozoal infections. Vet Parasitol 2006; 140(3-4): 189-203. http://dx.doi.org/10.1016/j.vetpar.2006.05.012. PMid:16828229.

Sousa RÁ, Lemos JF, Farias LA, Lopes CD, Santos KR. Seroprevalence and risk factors for Toxoplasma gondii infection in pigs in southern Piauí. Rev Bras Parasitol Vet 2014; 23(1): 98-100. http://dx.doi.org/10.1590/S1984-29612014015. PMid:24728369.

Tsutsui VS, Navarro IT, Freire RL, Freitas JC, Prudencio LB, Delbem ACB, et al. Soroepidemiologia e fatores associados à transmissão do Toxoplasma gondii em suínos do norte do Paraná. Arch Vet Sci 2003; 8(2): 27-34. http://dx.doi.org/10.5380/avs.v8i2.4030.

Valadas S, Minervino AHH, Lima VMF, Soares RM, Ortolani EL, Gennari SM. Occurrence of antibodies anti-Neospora caninum, anti-Toxoplasma gondii, and anti-Leishmania chagasi in serum of dogs from Pará State, Amazon, Brazil. Parasitol Res 2010; 107(2): 453-457. http://dx.doi.org/10.1007/s00436-010-1890-2. PMid:20445991.

Valença RMB, Mota RA, Anderlini GA, Faria EB, Cavalcanti ÉFSTF, Albuquerque PPF, et al. Prevalência e fatores de risco associados à infecção por Toxoplasma gondii em granjas suinícolas tecnificadas no Estado de Alagoas. Pesq Vet Bras 2011; 31(2): $121-126$. http://dx.doi.org/10.1590/S0100-736X2011000200005.

Vidotto O, Navarro IT, Mitsuka R, Freire RL, Freire RL. Estudos epidemiológicos da toxoplasmose em suínos da região de Londrina - PR. Semina: Ciênc Agrár 1990; 11(1): 53-59. http://dx.doi.org/10.5433/1679-0359.1990v11n1p53.

Vitaliano SN, de Mendonça GM, de Sandres FA, Camargo JS, de Tarso P, Basano SA, et al. Epidemiological aspects of Toxoplasma gondii infection in riverside communities in the Southern Brazilian Amazon. Rev Soc Bras Med Trop 2015; 48(3): 301-306. http:// dx.doi.org/10.1590/0037-8682-0040-2015. PMid:26108008. 